\title{
Visiting Places
}

\begin{abstract}
In this chapter we look at notions of place, as outlined in work in human geography, tourism studies and other applied social fields. We consider the distinction between spaces and places and on how different experiences of place arise in the traveller. This is important to our understanding of tourist and other travel experiences, and to experiencing a sense of place in digital environments. Despite some commonalities, we find that digital travel is unlike physical travel in many significant respects, but that the experience of a place can, in some circumstances, be similar. For digital travel and digital experiences, place attachment is relevant for places that a person knows well. We conclude that a digital experience can become a spatial experience if our bodily senses are invoked by the virtual place.
\end{abstract}

Keywords Place · Tourism · Human geography · Insideness · Hedonic consumption

\section{INTRODUCTION}

Digital technology can be used to create a fantasy world (Book, 2003), and also to replicate a place that actually exists. If a digital environment replicates a place a person could physically visit, what experience is created

(C) The Author(s) 2022

I. Tjostheim and J. A. Waterworth, The Psychosocial Reality

of Digital Travel, https://doi.org/10.1007/978-3-030-91272-7_4 
and how can we understand it? This is an underlying theme of the book. In the last chapter, we examined various views and findings on the sense of being present in another place, other than the place where the physical body is located. We presented this as a key distinction between physical travel and digital travel: the location of the traveller's physical body.

In this chapter we examine different notions of place, as outlined in work in tourism studies and other applied social fields; how and when different experiences of place arise for the traveller. We also stress that virtual travel is unlike physical travel in many significant respects, drawing on well-established theoretical accounts of travel emphasising the importance for the overall travel experience of experiencing departure from the present place (home), the journey itself and the process of arrival (and "incorporation") at a distal place.

Several authors have suggested that the ever-expanding move of society towards electronic communication in some ways destroys the sense of place underlying many social interactions, social conventions and rituals. In critically discussing this view, we are influenced by the social geographer Relph, who reinterpreted the person-environment relationship and how individuals experience a place phenomenologically. We discuss the value of how Relph (1976) defines experience of places as "fusions of buman and natural order... [places are] the significant centers of our immediate experiences of the world".

A place can be somewhere we leave, and also somewhere we arrive. Between is the journey, the travel (from the French travail), the work that takes us from the former to the later. At the place of arrival, the traveller needs to be assimilated into the place, and this is only fully possible when the necessary cues are "in place". Insights into the assimilation process are drawn from the second-home literature, among other sources.

As a step to integrating the contributions from different authors, we present a framework later in the chapter for evaluating the extent to which we can describe a digital travel experience as an actual travel experience. We distinguish between the pre-trip phase, the travel and being there phase and the post-visit phase. The key question is: to what extent and in what ways is the digital experience similar to or different from the in situ experience? In some cases, they are, or are perceived, as different. In other cases, the answer is that there is weak relationship to the actual in situ experience, or a strong one-it is a similar experience. 


\section{Sense of Place}

\section{Spaces and Places}

The term destination is frequently used in the travel literature. Most often it refers to a geographical place. Space is related term, as in public or private spaces. What is the difference between a space and a place? According to Mingers (2001), we experience space in terms of objects and their relations to each other-next to, on top of, beside - and so on. To Harrison and Dourish (1996) the relationship between place and space is essentially a distinction between two accounts of spaces. The first is an experiential while the second is geometrical (Brewer \& Dourish, 2008). Ciolfi (2004) uses the terms in a similar manner. He defines place as experienced space, and place is also often used as a geographical term, indicating what occupies a location.

The social aspect is one of the key components in all human experiences, and for sense of place. Meyrowitz (1986) observed that modern communication media commonly lack the sense of place that would frame the social behaviours of people meeting physically. People may have what seem to be face-to-face encounters, and yet they are not, since the participants are in different physical places. They do not share an experience of being in the same place and they behave in ways that would be inappropriate if they did - their behaviour is "out of place". Lentini and Decortis (2010: 408) write "Sense of place refers to how people apprehend physical space not only through the perception of its spatial characteristics, but also through the awareness of the social cues related to it". The history of a place, what is it known for, events that have happened there or are going to happen there, is also part of the place construct.

\section{Human Geography and Edwards Relph's Place Theory}

In his inaugural editorial of Tourism Geographies, Alan Lew (1999) pointed out that the field of tourism research is characterised by an overrepresentation of studies that bear a geographic orientation. This is not surprising since the concept of place is one of the core constructs in human geography (Kaltenborn, 1998). Tourists visit places. Therefore, it is reasonable that destinations and attractions represent core subjects in the tourism research terminology (Tribe \& Xiao, 2011).

Geographers commonly use the term sense of place. It is a relational concept (Sack, 1992) that must be understood within the context of 
human-environment relationships. Kaltenborn (1998) argues that the meaning of place is not inherent in the properties of nature, but rather interpreted and constructed by humans in particular contexts and situations. For Cheng et al. (2003) place emerges in the intersection of three spheres: social and political processes, the physical, and social and cultural meanings.

In most cases, geographers study residents and not visitors, but sense of place is also relevant in the context of tourism. In tourism, there is stream of research on visits to outdoor environments such as national parks (Kyle \& Chick, 2007; Williams et al., 1992; Williams \& Vaske, 2003). One of the central concepts used by Williams, Kyle and others is place attachment; that is, a bond that a person might have to a particular place. Researchers in human geography use the concept of place attachment to explain why people visit the same recreational park again and again. Also, researchers on the topic of second homes (e.g. Jaakson, 1986) use place attachment to understand the place experience (Gustafson, 2001; Stedman, 2006; Williams \& Kaltenborn, 1999). For digital travel and digital experiences, place attachment can be a relevant concept for places that a person knows well.

The term tourism experience is frequently used, but is not a term commonly used by geographers who, according to Li (2000), prefer the term "geographical consciousness" to relate to the human experience of space, place and the aesthetic elements of a place. Li (2000) argues that the concept of geographical consciousness has been overlooked by tourism research although it is closely related to the tourism experience. $\mathrm{Li}$ adds that insights from geographers, particularly Edward Relph and $\mathrm{Yi}-\mathrm{Fu}$ Tuan, are relevant for the field of tourism because "tourism experience is intimately joined with a tourist's cognition such as geographical consciousness" (Li, 2000: 877).

Relph is the author of the frequently cited monograph Place and Placelessness (1976). According to Seamon (1982), Relph reinterpretes phenomenologically the person-environment relationship and how individuals experience a place. Relph defines experience of places as "fusions of human and natural order ... [places are] the significant centers of our immediate experiences of the world" (p. 141). His insideness-outsideness concept reflects the nature of one's involvement with a place. It is reasonable to argue that for a place experience the insideness types of experience are more relevant and fit better for residents than visitors while the outsideness types are more relevant for and have a better fit with visitors than 
residents. Relph's seven types of place experience are presented in Table 4.1.

Building on Relph's work, the sociologist Gustafson (2001) proposed a three-pole triangular model with the components self, environment and others. Turner and Turner (2006) applied Gustafson's model in a VR context. They argued that when studying virtual applications, and in particular those that mirror the physical world, Gustafson's model and Relph's theory both seem appropriate. Gustafson, however, emphasises people, the life of the people living in a place, and to a lesser extent the physical environment. A place is a phenomenon by which their behaviour can be described, explained and predicted (Snepenger et al., 2007).

The philosopher Edward Casey (2001) distinguished between dwelling as residing and dwelling as wandering, and also emphasised bodily engagement. Casey defines place in consonance with Merleau-Ponty's term "lived body". To Merleau-Ponty the lived body consists in an I can, a practical engagement in the world. According to Casey (2001: 718)

Table 4.1 Relph's seven types of place experience

\section{Edward Relph's Place Theory}

\section{Existential insideness:}

Feeling of attachment and being at home, experience of place as full of meanings without self-conscious reflection

Behavioral insideness:

The place is perceived as objects and activities. Awareness of the distinctiveness of the place and engagement with the place

\section{Empathetic insideness:}

A concern for and interest in the place, but not necessarily directly involved with or agreeing to the meaning of the place (to others)
Existential outsideness:

Sense of not belonging, feeling of separation, alienation, lack of meanings and (reflective) un-involvement

\section{Objective outsideness:}

Place is a thing to be studied and manipulated A dispassionate attitude, a separation and distance between person and place

\section{Incidental outsideness:}

Place is experienced as incidental background for activities, what the person is doing overshadows where the person is

\section{Vicarious insideness:}

Experience of place in a secondhand or vicarious way without physically visiting the place, the person is involved with the place, a transportation through imagination 
"only the body holds together, in one coherent entity, the sense of place, the past pertinent to that place (that is, via body memories), and the orienting power which place requires. The body is the only aspect of our being - individual or collective - capable of performing place, that is to say, making place a living reality". Seamon (2018: 14) comments that Merleau-Ponty says little about the significance of place directly, but: "his perspective does much to clarify its integral relationship with the lived body and human situatedness".

For digital travel and digital experiences, a focus on the body might at first been seen as irrelevant. We suggested in Chapter 3 that what distinguishes digital travel is that the traveller's body can be seen as being left behind. But this is only half the story. In our discussion of Merleau-Ponty, and research that build his theoretical contributions, we saw the importance of evoking bodily reactions. A digital experience can be a spatial experience and our bodily senses are then invoked by the virtual place. In digital travel, the body is located in one physical place, but at least some embodied sensory experiences are invoked somewhere else-in a digital place.

\section{Marketing and Hedonic Consumption}

Tourists are, or most often can be seen as, consumers. Consumers may process information from either a hedonic or a utilitarian perspective depending on their goals (Pham, 1998; Shiv \& Fedorikhin, 1999). In the marketing literature, the two articles by Holbrook and Hirschman (1982) and Hirschman and Holbrook (1982) on hedonic consumption are seminal. According to Hirschman and Holbrook (1986: 219), consumption experience is "an emergent property that results from a complex system of mutually overlapping interrelationships in constant reciprocal interaction with personal, environmental, and situational inputs". It is the synthesis of the affective and cognitive actions and reactions that consumers have during their interface with products, services and the environment of the marketplace.

The articles by Holbrook and Hirschman have had an influence on the field of tourism marketing because the tourism experience emphasises experiential aspects of visiting places. For some travellers, hedonic might describe quite well what they do and seek on their vacation. For others, utilitarian aspects might be more important. Some visitors also develop an affective connection with specific places or destinations 
(Giuliani \& Feldman, 1993; Hidalgo \& Hernandez, 2001). The experiential qualities of a tourist destination's offerings are something that tourism marketers recognise as significant for travellers. Shopping is a common tourist activity, and therefore hedonic and utilitarian consumption have been used to capture and analyse shopping as a tourism activity (Jones et al., 2006).

Some researchers conceive and conceptualise a tourist destination as an amalgam of components that form a holistic experience of the place visited (Murphy et al., 2000). Tourism is often referred to as a hedonic consumption experience (Govers \& Go, 2005; Govers et al., 2007; Vogt \& Fesenmaier, 1998). Snepenger et al. (2004) investigated the meanings associated with a spectrum of tourism places. They found that tourism places could be differentiated in terms of their normative, hedonic, utilitarian, social and consumption meanings. Snepenger et al., (2004: 115) posit that places serve distinct functions in people's lives and "the greater the tourism demand for a place, the more hedonic the normative meanings of experiences at the place".

Investigations of the hedonic and utilitarian components of consumption have been addressed in various disciplines including advertising. In advertising research, it is not uncommon to use virtual environments or virtual applications (Ping et al., 2010; Goh et al., 2014). Some researchers in this field use the term "advergames". According to Dahl et al. (2009), an advergame tries to offer consumers an interactive entertainment so that the player may form an emotional connection between the game and the brand featured within it. In a recent paper by Speilmann et al. (2018), respondents (in several studies) were instructed to think about the last memorable experience they had when traveling to a destination. Based on the empirical results and analysis, the authors proposed a place authenticity scale. A key element in a memorable experience concept is realness, which concerns the availability of believable facts and accuracy in rendition. These factors play a similar role in a digital experience as in an in situ experience.

There are many interesting findings from advergame studies, and one conclusion is that it makes sense to use games and 3D environments for product placement, advertising research and shopper studies (Jiang \& Benbasat, 2004; Lau et al., 2014). While some of the researchers give explicit tasks to the participants in the advergame, for instance, to do shopping, others do not give any tasks besides using the game application. When designing a study for virtual environments as tourist locations, it is 
relevant to build on these advergames studies because they typically focus on behavioural intention and experiential aspects.

\section{Intention to Visit a Place and Word of Mouth}

In an e-commerce context, purchase intentions have been used in several studies (Ahn \& Bailenson, 2011; Chen et al., 2019; Griffith \& Chen, 2004; Jiang \& Benbasat, 2007; Kim \& Shim, 2002; Li et al., 2002, 2003; Suh \& Chang, 2006) to gauge later behaviour. The equivalent in a tourism context is the intention to visit a place or destination. The vividness of information can sometimes but not always increase its persuasive power (Taylor \& Thompson, 1982) and a direct experience can influence persuasion (Fazio \& Zanna, 1978; Wu \& Shaffer, 1987), and therefore intention to purchase and, presumably, intention to visit a place.

In consumer research, word of mouth (WoM) is a well-established concept (Arndt, 1967; Richins, 1983) to help predict purchase intentions. Word of mouth is defined by Anderson (1998) and Singh (1988) as all informal communications between a customer and others regarding evaluations of goods or services. The WoM concept is also used in studies of service industries (Maxham, 2001; Yu \& Dean, 2001) and a number of other fields (Schmäh et al., 2017). In tourism there seems to be a preference for the terms recommendation- and destination-WoM (Bigne et al., 2001; Simpson \& Siguaw, 2008). Both concepts, intention to visit and word of mouth, are viewed as relevant and useful for empirical studies of the phenomena in question.

\section{Experiencing Sense of Place in A VirTUAL ENVIRONMENT}

Smyth et al. (2015) conceptualised the virtual experience of place in a way that contains the same components as or proposed in Relph's model of place. However, in Smyth et al.'s model, physical aspects, affective experiences and activities are all mediated by technology. It is not possible to reproduce the exact experience of being in a physical place, but Smyth et al. argue that it is possible to produce a convincing illusion of nonmediation, a feeling of being there. In Chapter 3 we discussed several different current interpretations of the factors involved in the creation of this kind of illusion. 
Traditionally, human geography has not focused on the role of technology, the experience of a place with or through media, but in telepresence research there is some interest in human geography. Turner et al. (2005: 10) argue that "Relph's discussion of 'insideness' and 'outsideness' offers a compelling insight for contextualizing the VR experience". They discuss insideness and outsideness in relationship to Heidegger's concept of dwelling. To Heidegger, dwelling is our thought about our relation to space. Shamai (1991) finds Relph's distinction between seven different degrees of outsideness and insideness in ways of sensing a place practical and useful. Shamai (1991: 349) writes:

Each different way of sensing the place can be seen as a different level on an ordinal scale; that is, starting with the lowest level of sense of place and 'climbing' up six more steps to reach the most intense and deepest way of sensing a place.

Relph uses the term vicarious insideness (Table 4.1), although very few tourism researchers use the concept of vicariousness. However, one work that does include the concept of vicariousness is of particular relevance for virtual tourism: Vicarious Journeys: Travels in Music (Connell \& Gibson, 2004: 7). The authors observe that "many albums from the 1950s and 1960s attempted to 'capture' the sounds of far-away places, vicariously transporting the armchair listener to idyllic holiday destinations, mysterious Pacific Islands, Alpine heights or cosmopolitan European streetscapes". The term "vicariously transporting" is of interest, and not only for what music can do, but as suggesting an experience induced by media technology. Destinations can influence image formation through secondary place interactions with consumers, so-called vicarious experiences (Kim \& Richardson, 2003).

McCarthy and Wright (2005: 921) in their discussion of technology, space and the experience of place write:

But people can also have a sense of place as they wander. People can in some meaningful way dwell in public spaces like arcades and parks as they move about them, shopping or just hanging out. People can clearly have a strong sense of place about a city as they wander around its winding streets. Increasingly, people dwell on street-corners and in the buses, trains or cars in which they spend hours travelling to and from work. But the experience of wandering can be considered dwelling only if the people involved feel settled. In contrast, if people's wandering is exploratory, if they are trying 
to find a place, get oriented, or simply moving between places, there is no dwelling or being in place.

Although not many in telepresence research have built on human geography, it is reasonable to reflect on and apply concepts from this field in studies of the feeling of being there and ask: just how is the body part of a telepresence experience? Raymond et al. (2017) refer to Evans and Stanovich's dual process theory in their discussion on affordance in sense of place research. Raymond et al. (2017: 5) write: "it remains unclear how the immediately perceived and sensory dimensions of sight, smell, hearing, taste, and touch (i.e. aspects of sensory experience) contribute to overall place meaning (2017: 5)". A recent study by Buzova et al. (2020) focused on sensory perceptions of how tourists evaluate their place experiences, based on a lexical analysis of blogs, and seeks to unpack the role of the senses in visitors' destination evaluations. As we saw in Chapter 3, the experience of presence is best understood as an example of Type1 processing: as immediate, instinctive and un-reflective. When we are preoccupied with trying to work out where we are, and how to find our way somewhere else, we engage in primarily Type- 2 processing-more logical and reflective. Our attention is channelled in such a way that we are not so aware of actually being there, of dwelling, in the current place.

\section{Insights from Non-digital Travel and Tourism}

In Chapters 2 and 3 we discussed aspects of feeling one is somewhere and the digital experience of being there in another place. But the telepresence experience cannot be understood without a reference to the travel and tourism experiences to places in situ. In this section, we look more closely at the travel and tourism perspective, of being there in situ. Below we draw attention to the work of the sociologist Eric Cohen $(1972,1979)$ and to tourism as an activity that is intrinsically motivated and can be studied from the individual traveller's point of view (Mannell \& Iso-Ahola, 1987; Pearce, 1991).

Cohen (1979) identified five modes of tourism experience: recreational, diversionary, experiential mode and existential modes. The first two, the recreational mode and the diversionary mode, are particularly relevant to our discussion. The recreational mode emphasises that the individual tourist steps outside the normal, the ordinary, in search of entertainment. It is well known that many tourists take part in activities 
that can be characterised as entertainment, such as visiting scenic places, visiting famous restaurants, and engaging in situational leisure activities. The second is the diversionary mode. The motivation here is to break out of the daily routines and stress of everyday life for a short while, by going to another place and not having the same routines and obligations.

As a step to integrating Cohen's contributions and those of other key authors in the field, we present (Table 4.2) a framework for evaluating the extent to which we can describe a digital travel experience as an actual travel experience. We distinguish between the pre-trip phase, the travel, the being there phase and the post-visit phase.

Tjostheim developed and tested an extended version of Edward Relph's types of placeness that included behavioural outsideness and vicarious outsideness (Tjostheim, 2020; see Table 4.3). As with Cohen's distinction between recreational or diversionary tourism experience, the three categories of outsideness-incidental, behavioural and vicarious outsideness-can serve as a counterpart, a yardstick to make sense of the telepresence experience. In Chapter 5 we report results from the use of a measure that included these additional types, to shed more light on the role of sense of place in digital travel experiences.

\section{Conclusions}

In this chapter we have examined notions of place, as outlined in work in tourism studies and other applied social fields and on how and when different experiences of place arise in the traveller. The distinction between spaces and places, and experiencing a sense of place, are important to our understanding of tourist and other travel experiences. These insights can be generalised to experiencing a sense of place in digital environments. Marketing and the notion of hedonic consumption are also useful in understanding travel and travellers, for example, through their intention to visit a place and provide word of mouth recommendations about it.

The tourist experience is an amalgam of different experiences. It involves all senses and therefore their impact should not be overlooked in efforts to theorise tourism's experiential dimensions (Dann \& Jacobsen, 2002, 2003; Edensor, 2006; Franklin \& Crang, 2001; Rickly-Boyd, 2009: 269, Ryan, 2010).

A key question concerns the extent and ways in which a digital experience similar to or different from the in situ experience. Virtual travel is 
Table 4.2 Framework for evaluating the extent to which a digital travel experience can be seen as an actual travel experience (bold indicates the most relevant)

\begin{tabular}{|c|c|c|c|}
\hline \multirow[t]{2}{*}{ In situ } & \multicolumn{3}{|l|}{ Digital } \\
\hline & $\begin{array}{l}\text { The pre-trip phase, the } \\
\text { anticipation of the travel } \\
\text { experience }\end{array}$ & $\begin{array}{l}\text { The travel phase, the } \\
\text { being there } \\
\text { Experience }\end{array}$ & $\begin{array}{l}\text { The post-visit } \\
\text { phase: remember } \\
\text { and sharing the } \\
\text { experience with } \\
\text { others }\end{array}$ \\
\hline Relph (1976) & & & \\
\hline Existential & No & No & No \\
\hline insideness & No & No & No \\
\hline Empathetic & No & No & No \\
\hline $\begin{array}{l}\text { insideness } \\
\text { Behavioural } \\
\text { insideness } \\
\text { Vicarious } \\
\text { insideness }\end{array}$ & No or weak & No or weak & No or weak \\
\hline Objective & No & No & No \\
\hline outsideness & Weak or similar to & Weak or similar to & No or weak \\
\hline Incidental & Weak or similar to & Weak or similar to & Weak \\
\hline outsideness & Weak or similar to & Weak or similar to & Weak \\
\hline $\begin{array}{l}\text { Vicarious } \\
\text { outsideness } \\
\text { Behavioral } \\
\text { outsideness } \\
\text { Existential } \\
\text { outsideness } \\
\text { Cohen (1979) }\end{array}$ & No & No & No \\
\hline Recreational & Weak or similar to & Weak or similar to & No or weak \\
\hline mode & Weak or similar to & Weak or similar to & No or weak \\
\hline Diversionary & No & No & No \\
\hline mode & No & No & No \\
\hline $\begin{array}{l}\text { Experiential mode } \\
\text { Experimental } \\
\text { mode }\end{array}$ & No & No & No \\
\hline Existential mode & & & \\
\hline Holbrook and & & & \\
\hline Hirschman (1982) & & & \\
\hline $\begin{array}{l}\text { Utilitarian } \\
\text { components }\end{array}$ & Weak & No & No \\
\hline $\begin{array}{l}\text { Hedonic } \\
\text { components }\end{array}$ & Weak or similar to & Weak or similar to & Weak \\
\hline
\end{tabular}


Table 4.3 Relph's types of sense of place with two new types of outsideness

\section{Relph's Place Theory}

including two new types (in colour)

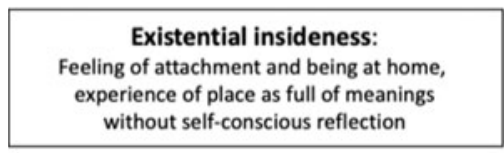

\section{Empathetic insideness:}

A concern for and interest in the place, but not necessarily directly involved with or agreeing to the meaning of the place (to others)

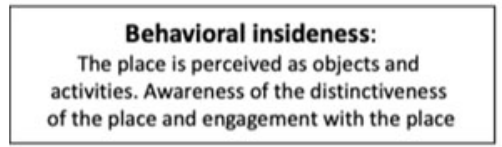

\section{Vicarious insideness:}

Experience of place in a secondhand or vicarious way without physically visiting the place the person is involved with the place, a transportation through imagination

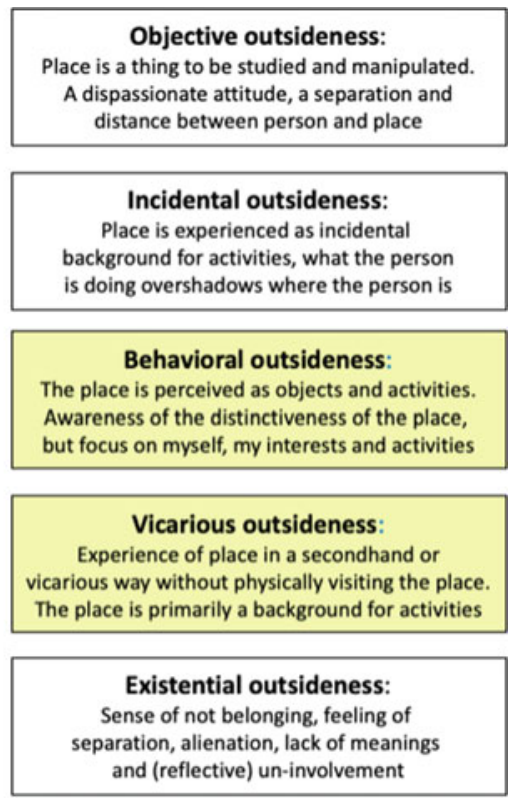

unlike physical travel in many significant respects, but the experience of a place-once one has the feeling of being there-may be more or less similar. For digital travel and digital experiences, place attachment can be a relevant concept for places that a person knows well. And a digital experience can become a spatial experience if our bodily senses are invoked in the virtual place. A key element in a memorable experience is perceived realness. Facts and accuracy play a similar role in digital experiences as in in situ experiences, as we shall see in the next chapter.

\section{REFERENCES}

Ahn, S. J., \& Bailenson, J. N. (2011). Self-endorsing versus other-endorsing in virtual environments. Journal of Advertising, 40(2), 93-106. https://doi. org/10.2753/JOA0091-3367400207

Anderson, E. W. (1998). Customer satisfaction and word of mouth. Journal of Service Research, 1(1), 5-17. https://doi.org/10.1177/109467059800 100102 
Arndt, J. (1967). Role of product-related conversations in the diffusion of a new product. Journal of Marketing Research, 4(3), 291. https://doi.org/10. $2307 / 3149462$

Bigné, J. E., Sánchez, M. I., \& Sánchez, J. (2001). Tourism image, evaluation variables and after purchase behaviour: Inter-relationship. Tourism Management, 22(6), 607-616. https://doi.org/10.1016/S0261-5177(01)00035-8

Brewer, J., \& Dourish, P. (2008). Storied spaces: Cultural accounts of mobility, technology, and environmental knowing. International Journal of HumanComputer Studies, 66(12), 963-976. https://doi.org/10.1016/j.ijhcs.2008. 03.003

Buzova, D., Cervera-Taulet, A., \& Sanz-Blas, S. (2020). Exploring multisensory place experiences through cruise blog analysis. Psychology \& Marketing, 37(1), 131-140. https://doi.org/10.1002/mar.21286

Casey, E. S. (2001). On Habitus and place: Responding to my critics. Annals of the Association of American Geographers, 91(4), 716-723. https://doi.org/ 10.1111/0004-5608.00270

Chen, Z., Cenfetelli, R., \& Benbasat, I. (2019). The influence of e-commerce live streaming on lifestyle fit uncertainty and online purchase intention of experience products. Hawaii International Conference on System Sciences. https://doi. org/10.24251/HICSS.2019.610

Cheng, A. S., Kruger, L. E., \& Daniels, S. E. (2003). 'Place' as an integrating concept in natural resource politics: Propositions for a social science research agenda. Society \& Natural Resources, 16(2), 87-104. https://doi.org/10. $1080 / 08941920309199$

Ciolfi, L. (2004). Situating "place" in interaction design: Enhancing the user experience in interactive environments. University of Limerick (Ireland).

Cohen, E. (1972). Towards a sociology of international tourism. Social Research: An International Quarterly, 39, 164-189.

Cohen, E. (1979). Rethinking the sociology of tourism. Annals of Tourism Research, 6(1), 18-35. https://doi.org/10.1016/0160-7383(79)90092-6

Connell, J., \& Gibson, C. (2004). Vicarious journeys: Travels in music. Tourism Geographies, 6(1), 2-25. https://doi.org/10.1080/146166803200 01722319

Dahl, S., Eagle, L., \& Báez, C. (2009). Analyzing advergames: Active diversions or actually deception. An exploratory study of online advergames content. roung Consumers, 10(1), 46-59. https://doi.org/10.1108/174736109109 40783

Dann, G., \& Jacobsen, J. K. S. (2003). Tourism smellscapes. Tourism Geographies, 5(1), 3-25. https://doi.org/10.1080/1461668032000034033

Dann, G. M. S., \& Jacobsen, J. K. S. (2002). Leading the tourist by the nose. In G. M. S. Dann (Ed.), The tourist as a metaphor of the social world (pp. 209235). CABI. https://doi.org/10.1079/9780851996066.0209 
Edensor, T. (2006). Sensing tourist spaces. In C. Minca \& T. Oakes (Eds.), Travels in paradox: Remapping tourism (pp. 23-35). Rowman \& Littlefield.

Fazio, R. H., \& Zanna, M. P. (1978). Attitudinal qualities relating to the strength of the attitude-behavior relationship. Journal of Experimental Social Psychology, 14(4), 398-408. https://doi.org/10.1016/0022-1031(78)90035-5

Franklin, A., \& Crang, M. (2001). The trouble with tourism and travel theory? Tourist Studies, 1(1), 5-22. https://doi.org/10.1177/146879760 100100101

Giuliani, M. V., \& Feldman, R. (1993). Place attachment in a developmental and cultural context. Journal of Environmental Psychology, 13(3), 267-274. https://doi.org/10.1016/S0272-4944(05)80179-3

Goh, K.-Y., Ping, J., \& National University of Singapore. (2014). Engaging consumers with advergames: An experimental evaluation of interactivity, fit and expectancy. Journal of the Association for Information Systems, 15(7), 388-421. https://doi.org/10.17705/ljais.00366

Govers, R., \& Go, F. M. (2005). Projected destination image online: Website content analysis of pictures and text. Information Technology \& Tourism, 7(2), 73-89. https://doi.org/10.3727/1098305054517327

Govers, R., Go, F. M., \& Kumar, K. (2007). Virtual destination image a new measurement approach. Annals of Tourism Research, 34(4), 977-997. https://doi.org/10.1016/j.annals.2007.06.001

Griffith, D. A., \& Chen, Q. (2004). The influence of virtual direct experience (vde) on on-line ad message effectiveness. Journal of Advertising, 33(1), 5568. https://doi.org/10.1080/00913367.2004.10639153

Gustafson, P. (2001). Meanings of place: Everyday experience and theoretical conceptualizations. Journal of Environmental Psychology, 21(1), 5-16. https://doi.org/10.1006/jevp.2000.0185

Harrison, S., \& Dourish, P. (1996). Re-place-ing space: The roles of place and space in collaborative systems. Proceedings of the 1996 ACM Conference on Computer Supported Cooperative Work - CSCW'96, 67-76. https://doi.org/ $10.1145 / 240080.240193$

Hidalgo, M. C., \& Hernández, B. (2001). Place attachment: Conceptual and empirical questions. Journal of Environmental Psychology, 21(3), 273-281. https://doi.org/10.1006/jevp.2001.0221

Hirschman, E. C., \& Holbrook, M. B. (1982). Hedonic consumption: Emerging concepts, methods and propositions. Journal of Marketing, 46(3), 92. https://doi.org/10.2307/1251707

Hirschman, E. C., \& Holbrook, M. B. (1986). Expanding the ontology and methodology of research on the consumption experience. In D. Brinberg \& R. J. Lutz (Eds.), Perspectives on methodology in consumer research (pp. 213251). Springer. https://doi.org/10.1007/978-1-4613-8609-4_7 
Holbrook, M. B., \& Hirschman, E. C. (1982). The experiential aspects of consumption: Consumer fantasies, feelings, and fun. Journal of Consumer Research, 9(2), 132. https://doi.org/10.1086/208906

Jaakson, R. (1986). Second-home domestic tourism. Annals of Tourism Research, 13(3), 367-391. https://doi.org/10.1016/0160-7383(86)90026-5

Jiang, Z., \& Benbasat, I. (2004). Virtual product experience: Effects of visual and functional control of products on perceived diagnosticity and flow in electronic shopping. Journal of Management Information Systems, 21(3), 111147. https://doi.org/10.1080/07421222.2004.11045817

Jiang, Z., \& Benbasat, I. (2007). The effects of presentation formats and task complexity on online consumers' product understanding. MIS Quarterly, 31(3), 475. https://doi.org/10.2307/25148804

Jones, M. A., Reynolds, K. E., \& Arnold, M. J. (2006). Hedonic and utilitarian shopping value: Investigating differential effects on retail outcomes. Journal of Business Research, 59(9), 974-981. https://doi.org/10.1016/j.jbusres.2006. 03.006

Kaltenborn, B. P. (1998). Effects of sense of place on responses to environmental impacts. Applied Geography, 18(2), 169-189. https://doi.org/10. 1016/S0143-6228(98)00002-2

Kim, H., \& Richardson, S. L. (2003). Motion picture impacts on destination images. Annals of Tourism Research, 30(1), 216-237. https://doi.org/10. 1016/S0160-7383(02)00062-2

Kim, Y. M., \& Shim, K. (2002). The influence of internet shopping mall characteristics and user traits on purchase intent. Irish Marketing Review, 15(2), 25-34.

Kyle, G., \& Chick, G. (2007). The social construction of a sense of place. Leisure Sciences, 29(3), 209-225.

Lau, K. W., Lee, P. Y., \& Lau, H. F. (2014). Shopping experience 2.0: An exploration of how consumers are shopping in an immersive virtual reality. Advances in Economics and Business, 2(2), 92-99.

Lentini, L., \& Decortis, F. (2010). Space and places: When interacting with and in physical space becomes a meaningful experience. Personal and Ubiquitous Computing, 14, 407-415.

Lew, A. (1999). Editorial: Tourism enclaves in place and mind. Tourism Geographies, 6(1), 1-1. https://doi.org/10.1080/1461668032000172283

Li, H., Daugherty, T., \& Biocca, F. (2002). Impact of 3-d advertising on product knowledge, brand attitude, and purchase intention: The Mediating role of presence. Journal of Advertising, 31(3), 43-57. https://doi.org/10.1080/ 00913367.2002.10673675

Li, H., Daugherty, T., \& Biocca, F. (2003). The role of virtual experience in consumer learning. Journal of Consumer Psychology, 13(4), 395-407. https:// doi.org/10.1207/S15327663JCP1304_07 
Li, Y. (2000). Geographical consciousness and tourism experience. Annals of Tourism Research, 27(4), 863-883. https://doi.org/10.1016/S0160-738 3(99)00112-7

Mannell, R. C., \& Iso-Ahola, S. E. (1987). Psychological nature of leisure and tourism experience. Annals of Tourism Research, 14(3), 314-331. https:// doi.org/10.1016/0160-7383(87)90105-8

Maxham, J. G. (2001). Service recovery's influence on consumer satisfaction, positive word-of-mouth, and purchase intentions. Journal of Business Research, 54(1), 11-24. https://doi.org/10.1016/S0148-2963(00)00114-4

McCarthy, J., \& Wright, P. (2005). Technology in place: Dialogics of technology, place and self. In M. F. Costabile \& F. Paternò (Eds.), Human-computer interaction-Interact 2005 (Vol. 3585, pp. 914-926). Springer. https://doi. org/10.1007/11555261_72

Meyrowitz, J. (1986). No sense of place: The impact of electronic media on social behavior (1. issued as an Oxford Univ. Press paperback). Oxford University Press.

Mingers, J. (2001). Embodying information systems: The contribution of phenomenology. Information and Organization, 11(2), 103-128. https:// doi.org/10.1016/S1471-7727(00)00005-1

Murphy, P., Pritchard, M. P., \& Smith, B. (2000). The destination product and its impact on traveller perceptions. Tourism Management, 21(1), 43-52. https://doi.org/10.1016/S0261-5177(99)00080-1

Pearce, P. L. (1991). Analysing tourist attractions. Journal of Tourism Studies, 2(1), 46-55.

Pham, M. T. (1998). Representativeness, relevance, and the use of feelings in decision making. Journal of Consumer Research, 25(2), 144-159. https:// doi.org/10.1086/209532

Ping, J. W., Goh, K. Y., \& Teo, H. H. (2010). Engaging consumers with advergames: An experimental evaluation of interactivity, relevance and expectancy. In Proceedings of the 31th international conference on information systems. Saint Louis, Missouri, December 12-15, 2010, Paper 221: 1-21.

Raymond, C. M., Kyttä, M., \& Stedman, R. (2017). Sense of place, fast and slow: The potential contributions of affordance theory to sense of place. Frontiers in Psychology, 8, 1674. https://doi.org/10.3389/fpsyg.2017.01674

Relph, E. (1976). Place and placelessness. Sage.

Richins, M. L. (1983). Negative word-of-mouth by dissatisfied consumers: A pilot study. Journal of Marketing, 47(1), 68. https://doi.org/10.2307/320 3428

Rickly-Boyd, J. M. (2009). The tourist narrative. Tourist Studies, 9(3), 259-280. https://doi.org/10.1177/1468797610382701 
Ryan, C. (2010). Ways of conceptualizing the tourist experience a review of literature. Tourism Recreation Research, 35(1), 37-46. https://doi.org/10. 1080/02508281.2010.11081617

Sack, R. D. (1992). Place, modernity and the consumer's world. The Johns Hopkins University Press.

Schmäh, M., Wilke, T., \& Rossmann, A. (2017, December). Electronic word-ofmouth: A systematic literature analysis. In A. Rossmann \& A. Zimmermann (Eds.), Digital enterprise computing (pp. 147-158). Gesellschaft für Informatik.

Seamon, D. (1982). The phenomenological contribution to environmental psychology. Journal of Environmental Psychology, 2(2), 119-140. https://doi. org/10.1016/S0272-4944(82)80044-3

Seamon, D. (2018). Merleau-Ponty, lived body, and place: Toward a phenomenology of human situatedness. In T. Hünefeldt \& A. Schlitte (Eds.), Situatedness and place (Vol. 95, pp. 41-66). Springer. https://doi.org/10. 1007/978-3-319-92937-8_4

Shamai, S. (1991). Sense of place: An empirical measurement. Geoforum, 22(3), 347-358. https://doi.org/10.1016/0016-7185(91)90017-K

Shiv, B., \& Fedorikhin, A. (1999). Heart and mind in conflict: The interplay of affect and cognition in consumer decision making. Journal of Consumer Research, 26(3), 278-292. https://doi.org/10.1086/209563

Simpson, P. M., \& Siguaw, J. A. (2008). Destination word of mouth: The role of traveler type, residents, and identity salience. Journal of Travel Research, 47(2), 167-182. https://doi.org/10.1177/0047287508321198

Singh, J. (1988). Consumer complaint intentions and behavior: Definitional and taxonomical issues. Journal of Marketing, 52(1), 93. https://doi.org/ $10.2307 / 1251688$

Smyth, M., Benyon, D., McCall, R., O’Neill, S., \& Carroll, F. (2015). Patterns of place: An integrated approach for the design and evaluation of real and virtual environments. In M. Lombard, F. Biocca, J. Freeman, W. IJsselsteijn, \& R. J. Schaevitz (Eds.), Immersed in media (pp. 237-260). Springer. https://doi. org/10.1007/978-3-319-10190-3_10

Snepenger, D., Murphy, L., Snepenger, M., \& Anderson, W. (2004). Normative meanings of experiences for a spectrum of tourism places. Journal of Travel Research, 43(2), 108-117. https://doi.org/10.1177/0047287504268231

Snepenger, D., Snepenger, M., Dalbey, M., \& Wessol, A. (2007). Meanings and consumption characteristics of places at a tourism destination. Journal of Travel Research, 45(3), 310-321. https://doi.org/10.1177/004728750 6295909

Spielmann, N., Babin, B. J., \& Manthiou, A. (2018). Places as authentic consumption contexts. Psychology \& Marketing, 35(9), 652-665. https://doi. org/10.1002/mar.21113 
Stedman, R. C. (2006). Understanding place attachment among second home owners. American Behavioral Scientist, 50(2), 187-205. https://doi.org/10. $1177 / 0002764206290633$

Suh, K.-S., \& Chang, S. (2006). User interfaces and consumer perceptions of online stores: The role of telepresence. Behaviour \& Information Technology, 25(2), 99-113. https://doi.org/10.1080/01449290500330398

Taylor, S. E., \& Thompson, S. C. (1982). Stalking the elusive 'vividness' effect. Psychological Review, 89(2), 155-181. https://doi.org/10.1037/0033-295X. 89.2.155

Tjostheim, I. (2020). Experiencing sense of place in a virtual environment: Real in the moment? [Report RR-20.02]. Umeä Universitet.

Tribe, J., \& Xiao, H. (2011). Developments in tourism social science. Annals of Tourism Research, 38(1), 7-26. https://doi.org/10.1016/j.annals.2010. 11.012

Turner, P., \& Turner, S. (2006). Place, sense of place, and presence. Presence: Teleoperators and Virtual Environments, 15(2), 204-217. https://doi.org/ 10.1162/pres.2006.15.2.204

Turner, P., Turner, S., \& Carroll, F. (2005). The tourist gaze: Towards contextualised virtual environments. Spaces, spatiality and technology (pp. 281-297). Kluwer Springer.

Vogt, C. A., \& Fesenmaier, D. R. (1998). Expanding the functional information search model. Annals of Tourism Research, 25(3), 551-578. https://doi.org/ 10.1016/S0160-7383(98)00010-3

Williams, D. R., \& Kaltenborn, B. P. (1999). Leisure places and modernity: The use and meaning of recreational cottages in Norway and the USA. In D. Crouch (Ed.), Leisure/tourism geographies: Practices and geographical knowledge (pp. 214-230). Routledge.

Williams, D. R., Patterson, M. E., Roggenbuck, J. W., \& Watson, A. E. (1992). Beyond the commodity metaphor: Examining emotional and symbolic attachment to place. Leisure Sciences, 14(1), 29-46. https://doi.org/10.1080/014 90409209513155

Williams, D. R., \& Vaske, J. J. (2003). The measurement of place attachment: Validity and generalizability of a psychometric approach. Forest Science, 49(6), 830-840.

Wu, C., \& Shaffer, D. R. (1987). Susceptibility to persuasive appeals as a function of source credibility and prior experience with the attitude object. Journal of Personality and Social Psychology, 52(4), 677-688. https://doi.org/10.1037/ 0022-3514.52.4.677

Yu, Y., \& Dean, A. (2001). The contribution of emotional satisfaction to consumer loyalty. International Journal of Service Industry Management, 12(3), 234-250. https://doi.org/10.1108/09564230110393239 
Open Access This chapter is licensed under the terms of the Creative Commons Attribution 4.0 International License (http://creativecommons.org/licenses/ by $/ 4.0 /$ ), which permits use, sharing, adaptation, distribution and reproduction in any medium or format, as long as you give appropriate credit to the original author(s) and the source, provide a link to the Creative Commons license and indicate if changes were made.

The images or other third party material in this chapter are included in the chapter's Creative Commons license, unless indicated otherwise in a credit line to the material. If material is not included in the chapter's Creative Commons license and your intended use is not permitted by statutory regulation or exceeds the permitted use, you will need to obtain permission directly from the copyright holder.

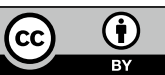

